\title{
Professor David Tuesday Adamo's Biblical Scholarship on Women: Reflections from an African-South African Mosadi
}

\author{
Madipoane Masenya (NgWan'a MPHAhlele) \\ (UNIVERSITY OF SOUTH AFRICA)
}

\begin{abstract}
One of the prolific writers in the discipline of African Biblical Hermeneutics is the Nigerian Old Testament (OT) scholar, Professor Tuesday David Adamo. In his tireless efforts to unlock the OT reality for African contexts, persuaded by his commitment to decolonise the subject of Biblical Studies, Adamo has made successful efforts to reflect on the African presence in the Old Testament. The present study seeks to engage Adamo's concept of African Biblical hermeneutics in order to investigate whether the author sufficiently discussed the theme of gender in his discourses. This research attempts to respond to the following two main questions in view of Adamo's discourses: (1) In Adamo's concerted effort of confirming the presence of Africa and Africans in the Hebrew Bible, does the woman question feature? (2) If so, how does Adamo navigate the question?
\end{abstract}

Keywords: Adamo, African Biblical Hermeneutics, African Woman, Bosadi, Hebrew Bible/Old Testament, Wife.

\section{A INTRODUCTION}

Professor David Tuesday Adamo's scholarship began to make an impact on the present author in the late 1980s. Adamo's commitment to the discipline of African biblical hermeneutics has been very helpful and refreshing especially given the American-and Eurocentric training and orientation which have shaped and continue to shape biblical scholarship on the African continent. His passion on and commitment to researching and foregrounding Africa and the Africans in the Christian Bible in his scholarship are worthy of note. Even a cursory look at most of Adamo's works persuades one to argue that the preceding research was born out of his commitment to three main concepts. First, the decolonisation (or rather, de-Eurocentrisation) of the contents and methods of biblical scholarship especially as they are theorised and practised on the African continent. Second,

1 This article was initially published in OTE 34/2. It is a welcome inclusion in this special issue dedicated to Professor David Tuesday Adamo. Submitted: 18/06/2020; peer-reviewed: 31/07/2020; accepted: 25/08/2020. Madipoane Masenya (Ngwan'a Mphahlele) "Professor David Tuesday Adamo's Biblical Scholarship on Women: Reflections from an African-South African Mosadi," Old Testament Essays 34 no. 2 (2021): 573 - 587. DOI: https://doi.org/10.17159/2312-3621/2021/v34n2a15. 
a deliberate foregrounding of the African context in his interaction with the biblical text. Like many proponents of African biblical hermeneutics, who refuse to be academic pies in the sky, Adamo deliberately allows present day concerns on the continent to be integrated with his research on the biblical texts. The words of Andrew Mbuvi come to mind here: "African Biblical Study refuses to deal with the Bible simply as an ancient text and demands that it be engaged to deal with present concerns, addressing issues that resonate with African (and world) realities." 2 Adamo's particular focus on the application of the Psalter within the lived experiences of selected Nigerian indigenous churches' members in recent years is commendable. Third, related to the preceding point, is the continued positive impact of the scholar's contributions on many grassroots African Christian(s). Hence, elsewhere in engaging the role of the Hagar character ${ }^{3}$ for present day communities, Adamo and Eghwubare could argue: "How would African people hear the stories of courage, perseverance, and faith that earned African Biblical women a place in salvation history if African biblical women are not identified ${ }^{4}$ Also, Adamo lauds Potiphar's wife, for having contributed, albeit in a problematic way to God's plan for God's people in Egypt: "The woman is pivotal to the survival of the Hebrews in Egypt. Her seduction initiated the event that brought the family of Jacob to Egypt, thus setting the stage for one of the major themes of the entire Bible, the Exodus or deliverance."

Pertinent though for the present investigation are the following two questions: (1) In Adamo's concerted effort of confirming the presence of Africa and Africans in the Hebrew Bible, does the woman question feature? (2) If so, how does Adamo navigate the question? As the word "gender" has become more nuanced in recent scholarship, thus transcending the binaries of male and female to include the LGBTQI+ persons, I have deliberately avoided the use of the

2 Andrew Mbuvi, "African Biblical Studies: An Introduction to an Emerging Discipline," Currents in Biblical Research 15/2 (2017): 154; See also Justin Ukpong as he argued, "The grid through which the Bible is read is developed from within Africa herself..." Justin S. Ukpong, "Developments in biblical interpretation in Africa: Historical and hermeneutical directions", in Bible in Africa, transactions, trajectories and trends (eds. Gerald O. West and Musa W. Dube, Leiden: Brill, 2001), 24; see also a recently published volume by Madipoane Masenya (Ngwan'a Mphahlele) and Kenneth Ngwa, Navigating African Biblical Hermeneutics: Trends and Themes from our Pots and Calabashes (Newcastle Upon Tyne: Cambridge Scholars Publishing, 2018, n.p.). The essays in the preceding collection show the writer's efforts to make Africa a hermeneutical lens through which the biblical text is read.

3 Adamo makes a concerted effort to foreground selected African women biblical characters as will be revealed in this essay, thus elevating the hitherto muted voices of African biblical women.

4 David T. Adamo and Erivwierho F. Eghwubare, "The African Wife of Abraham," Old Testament Essays 18/3 (2005): 456.

5 David T. Adamo, "The Nameless African Wife of Potiphar and her Contribution to Ancient Israel," Old Testament Essays 26/2 (2013): 221. 
preceding word to engage the Adamo material on women. As a matter of fact, a glimpse on Adamo's works on members of the female folk, at least the works with which one has interacted, hardly mentions the following words and/or phrases typical of works written by gender-conscious biblical scholars: gender, male, female, sexuality and/or sexual orientation. In this essay, I will employ the bosadi (womanhood-redefined) approach to the reading of Adamo's works on women. A brief discussion of the bosadi approach is now in order.

\section{B WHAT NOW OF THE BOSADI APPROACH?}

The bosadi framework was coined from my commitment to making "Africa" a hermeneutical lens ${ }^{6}$ for reading the biblical text. The term mosadi (for woman) does not only occur in the Northern Sotho setting, but also in other South African indigenous languages, for example, wansati (Xitsonga); umfazi (isiZulu); musadzi (Tshivenda) ${ }^{7}$; mosadi (Setswana and Sesotho). ${ }^{8}$ As a matter of fact, the root - (s) adi does occur in other African languages outside of South Africa (e.g., mwasi in the Mongo of DRC; -mkazi in Chewa, Malawi and sadi in the Tswana of Botswana, among others).

The generic Northern Sotho word mosadi (cf. Hebrew îšs̄āh) can be used to designate a woman irrespective of her marital status. Thus although the preceding observation is noteworthy, traditionally and to an extent even today, the word mosadi seems to be a fitting designation for a married woman, a mohumagadi, a word translated as "wife" in English. As can be speculated, heterosexual marriages appear to be the norm in many African and global cultures. The latter definition of mosadi, as it will be observed in the next section of the present essay, seems to fit Adamo's scholarship/writings on woman in the Hebrew Bible.

6 In the light of this preoccupation with Africa and its concerns, it becomes a misunderstanding to regard the bosadi approach as a local approach, restricted only to the Northern Sotho. See Sarojini Nadar, "A South African Womanist Reading of the book of Ruth," in Other Ways of Reading: African Women and the Bible (ed. Musa W. Dube: Atlanta: SBL/Geneva: WCC Publications, 2001), 159-175; Tinyiko S. Maluleke, "African 'Ruths,' Ruthless Africans: Reflections of an African Mordecai," in Other Ways of Reading: African Women and the Bible (ed. Musa W. Dube: Atlanta: SBL / Geneva: WCC Publications, 2001), 237-251. Although the Northern Sotho AfricanSouth African context serves as a point of departure within the bosadi framework, Masenya (ngwan'a Mphahlele)'s goal was to include other African-South African contexts. The latter would also not be far-fetched compared to other African contexts.

7 See Lufhuluvi M. Mudimeli, "The Impact of Religious and Cultural Discourses on the Leadership Development of Women in the Ministry: A Vusadzi (Womanhood) Perspective" (Unpublished DTh. thesis, University of South Africa, Pretoria, 2010).

8 Madipoane Masenya (Ngwana' Mphahlele), How Worthy is the Woman of Worth? Proverbs 31:10-13 in an African-South African Context (Peter Lang: New York, 2004), 122. 
African women, encountering varied life-denying forces like sexism in the broader South African society and sexism in the African culture, postapartheid racism, classism, HIV and AIDS, ecological degradation among others, are made the main hermeneutical foci in the interpreter's interaction with the biblical text. A mosadi is defined as female who is created in God's image, complete with or without a male human being as a marital partner (wife) nor children (as a mother). Although recognising and embracing the African spirit of communality, a mosadi still retains her identity as a full human being. ${ }^{9}$

With the above brief introduction to the bosadi approach, let us now turn to Adamo's works on women. The discussion will focus on the following four themes:

1. An African biblical woman,

2. Woman as wife (and mother),

3. Woman as a positive agent for the welfare of the nation (then and today?), and

4. Reading of Adamo's works on women in present-day South Africa.

The following research outputs by David Tuesday Adamo will form the core of the discussion in the present essay:

1. "The African Wife of Abraham (Gen. 16:1-16;21:8-31),"10 co-authored with Eghwubare.

2. "The African Wife of Joseph, Asenath (Gen. 41:45; 41:50, 46:20)."11

3. "The African Wife of Jeroboam (Ano?): An African Reading of I Kings $14: 1-18 . " 12$

4. "The African Wife of Solomon (1 Kings 3: 1; 9:16; 7:8; 11:1)."13

5. "The Nameless African Wife of Potiphar and her Contribution to Ancient Israel (2013)."14

Two main words which are helpful for the present investigation recur in the above works, that is: "African" and "wife." What now of the African Biblical woman?

9 Masenya (Ngwan'a Mphahlele), How Worthy is the Woman of Worth?, 122.

10 David T. Adamo, and Erivwierho F. Eghwubare, "The African Wife of Abraham." Old Testament Essays 18/3 (2005): 455-471.

11 David T. Adamo, "The African Wife of Joseph, Asenath (Gn. 41:45, 50; 46:20)." Journal for Semitics 22/2 (2013): 409-425.

12 David T. Adamo, "The African Wife of Jeroboam (Ano?): An African Reading of I King 14:1-18," Theologia Viatorum 37/2 (2013): 71-89.

13 David T. Adamo, "The African Wife of Solomon (I Kings 3:1;9:16; 7:8;11:1)," Journal for Semitics 23/1 (2014): 1-20.

14 Adamo, "The Nameless African Wife of Potiphar," 221-246. 


\section{The African Biblical Woman}

In the article titled, "The Nameless African Wife of Potiphar and Her Contribution to Ancient Israel," 15 David Tuesday Adamo argues: "Since this article is part of the research that considers Africa and Africans in the Bible, ${ }^{16}$ identifying Egypt and the wife of Joseph as Africa and Africans promotes African presence in the Bible which has not been recognised and accepted by many Euro-American and African biblical scholars." ${ }^{17}$ Elsewhere, Adamo also comes to the following conclusion: "Therefore, if we accept Egypt as an African country and that ancient Egyptians are Africans, then the assumption that the African wife of Joseph is an Egyptian and African is correct. One will be correct to consider her as African wife of Joseph. ${ }^{18}$ Adamo and Eghwubare write: "The preceding discussion is an attempt to affirm beyond any doubt, the Africanness of the ancient Egyptian people...Hence, Hagar can safely be described as an African, and in fact a black African woman."19

In my view, the preceding quotes provide the readers of Adamo's works, a window into his engagement with texts about what he prefers to name: "African biblical women." Rather than the conventional phrase, "African women in the Bible," I will stick to Adamo's designation that is "African biblical women." The

\footnotetext{
15 Adamo, "The African Wife of Joseph," 409-425.

16 Italics are mine.

17 Adamo, "The African Wife of Joseph," 413.
}

18 In the case of Jeroboam's wife, Adamo goes beyond what may be viewed as the bias of the Masoretic Text against the identity of the woman as an African. He therefore prefers the LXX's rendering as the latter clearly depicts the Egyptian (read: African) identity of Jeroboam's wife. "The MT suppresses not only the name of the African wife of Jeroboam but also her African identity; unlike her presentation in the Septuagint". After engaging the different translations on the narrative regarding the Jeroboam cycle, Adamo finds pertinent the fact that there was/is a Greek Bible which specifically featured the name of Jeroboam's wife (Ano) and her country that is (Egypt/Africa). In Adamo's view, the MT regrettably, refuses to mention the preceding fact. Consequent to Jeroboam's relative longer sojourn in Egypt//Africa, he contracted a diplomatic marriage with Pharaoh Shishak, who was at the time, a contemporary and enemy of Solomon. Adamo then argues for the view that it is thus relatively certain that the woman who was married to Jeroboam, is the nameless woman, pharaoh's daughter who features in I Kings 14:1-18. See Adamo, "The African Wife of Joseph," 413.

19 In their engagement with the Hagar narrative, the Adamo and Eghwubare make a story come alive with new insights as they bring it to bear on a contemporary African context such as that of the Urhobo of Nigeria. They highlight the importance of the chief wife in the decision making processes; arguing for the position of Hagar as a wife (not a concubine) and come to the following conclusion: "One important fact is clear from the above discussion. An African reader of Hagar's story is in an advantageous position to understand this story because of the closeness of African culture and the biblical culture" (see Adamo \& Eghwubare 2005:461). 
preceding designation, strange as it might appear, seems to me to be in line with what is the core agenda of Adamo's scholarship in general and his engagement with biblical women characters in particular, that is, the insistence that the Bible is not only replete with many references to Africa and the Africans; but also that Africans feature as playing critical roles in the biblical text. The presence of many Africans in the Bible, including the African wife of Joseph for example, enabled the Bible to have its present shape, thus highlighting the role which Africans played in salvation history/the sacred texts of Christianity. For example, for Adamo, the African identity of Solomon's wife and her contribution to ancient Israel is pertinent:

Pharaoh's daughter's influence was significant. Her economic, political and administrative contributions increased Israel's prosperity, and the political influence enabled Israel to have relative peace during Solomon's time. If all these contributions and influence are considered as an aspect of African contribution no one should deny the contribution of the daughter of Pharaoh who became Solomon's wife. ${ }^{20}$

So, the wives of Potiphar, Abraham, Joseph, Solomon and Jeroboam, are not just female characters in the Hebrew Bible; they are African descendants, Adamo claims. The justification of the preceding claim is unpacked in the following pattern $^{21}$ : Adamo first argues that Egypt, contra the views of many a Eurocentric scholar, ${ }^{22}$ has always been a part of Africa. He then proceeds to make an attempt to trace the pharaoh who has (could have) made a political alliance (through his daughter's marriage) with a specific key figure in Israelite history; then proceeds to show how such an Israelite leader had married a daughter of Pharaoh ${ }^{23}$ (read African wife of So and So). As he engages a specific woman character, he will also reveal the specific wife's influence on her husband's life, and thus subsequently, her "indirect" role in the shaping of the history of biblical Israel. For example, in his article on "The African wife of Solomon (1 Kings 3: 1; 9:16;

20 Adamo, "The African Wife of Solomon," 17.

21 He starts by levelling a critique against Eurocentric artists and Bible commentators about their tendencies and of deliberate efforts to de-Africanise the Bible citing a few scholars, mostly African American Biblical scholarship; laments the insufficient attention given to the status and role of African Biblical women. He raises the following critical question: "How would African people hear the stories of courage, perseverance, and faith that earned African Biblical women a place in salvation history if African biblical women are not identified?" (see Adamo and Eghwubare 2005:456).

22 Elsewhere Adamo argues: “...many modern biblical scholars are still in doubt as to whether Egypt is in Africa or in Europe, and whether Egyptians are Africans or Europeans" (see Adamo 2013:410). Even the Egyptians themselves are believed to have considered Africa as their place of origin and not Asia.

23 The African women engaged with are always linked to royalty, the daughters of Pharaoh. 
$7: 8 ; 11: 1),{ }^{\prime 24}$ Adamo engages the question of the historicity of Solomon and ends up supporting the view that Solomon was a historical figure. Subsequently, he then argues that if it can be maintained that Solomon did exist and that he had an African (Egyptian) father-in-law, then the influence and contribution of the wife of Solomon ought not to be dismissed as an invention. ${ }^{25}$ Even if Solomon's African wife carries no name in the biblical text, he argues, even if both Solomon and his wife are not attested in Archaeology, the marriage between the two represents an aspect of African influence as well as Solomon's wife's contribution to ancient Israel. The Biblical African woman engaged with in the preceding discussion is heterosexually married to a man of political stature. We now turn our attention to the preceding aspect, that is, African woman as wife.

\section{Woman as Wife (and Mother)}

The African woman discussed in Adamo's works on women is married. The husband is almost always a man of stature as the following examples will show. Solomon and Jeroboam were Israelite kings. Joseph was elevated to a position of being second in charge to the Egyptian king while Potiphar was one of the significant political figures in Egyptian history. Abraham is one of the most important figures in the context of the early beginnings of Israelite history. Overall, the husbands of the mostly nameless African women in Adamo's scholarship are powerful men. Would it thus be an exaggeration to argue that wives of such men, nameless as most of them are portrayed, were not powerless? So, the scholar's engagement with the preceding women characters, happens in the context of, or by virtue of the women's connections to men in a heterosexual marriage relationship. The exception to the preceding "rule", though, is notable in his co-authored piece of "the African wife of Abraham" (read: Hagar). Although the article's title retains the conventional phrase "wife of Abraham," in my view, the essay has more to do with Hagar's relationship with the deity than with Hagar as a wife to Abraham. The article's preoccupation with an individual woman's connection with the deity is a worthy engagement in the context of the emancipation and empowerment of African women. Why? An (African) woman is celebrated as an individual woman not by virtue of her relationship with a man (in a marriage of convenience - for political alliances? ${ }^{26}$ ),

\footnotetext{
24 Adamo, "The African Wife of Solomon," 1-20.

25 Then follows the author's analysis of the contradictory views of the historicity of Solomon and his marriage with the daughter of Pharaoh while arguing for the historicity of the character. This section is then followed by the author's arguments for the existence of Africa and Africans in the Bible (cf. Egypt as part of Africa) consequently claiming Africanness as an aspect of the identity of Solomon's Egyptian wife. See Adamo, "The African Wife of Solomon," 2.
}

26 The marriages, Adamo argues, were as it was the tradition in the Ancient Near East, meant to seal the political alliances between the countries involved (cf. Egypt and Israel 
but like prominent male figures in the $\mathrm{HB}$, in relation to the deity. In the same article, the inclusion of a section on the Urhobo marriage customs serves, in the view of the authors, to reveal the relationship between the biblical marriage customs and that of the Urhobo people, an aspect which also foregrounds the role of women as wives. However, even then, the discussion foregrounds the role of the chief wife in that specific Nigerian context. In that way, the author indirectly foregrounds the Sarah rather than the Hagar story. It also fails to engage critically with the challenge posed by polygamy to the women involved. ${ }^{27}$

The wives in the works under investigation are not only married to powerful men; they mostly come from powerful family/families, the house of pharaoh in Egypt. Hence, Egypt is the African country that gets the whole lion's share in Adamo's works on basadi. Similarly, the women who are made visible, raised as it were from patriarchal ashes are, except in the case of Hagar, Egyptian women of class. Most of the marriages, Adamo argues, were as it was the tradition in the Ancient Near East, meant to seal political alliances between the countries involved (cf. Egypt and Israel in the present cases).

Adamo is persuaded that the African women of these powerful men influenced their husbands' lives both negatively and positively. In the case of Solomon's chief wife, for example, her African ancestry may have influenced the king's life both socially, politically and religiously. As a senior wife like in the African tradition, Solomon's wife may have had a share in the polygamous relationships of her husband. He argues, "If it is accepted that Egypt is an African country and his chief wife is from Egypt, it is probable that Solomon was influenced to marry so many foreign wives by his first wife, as it is in African culture." 28 Adamo also attributes the polytheism of Solomon to his first wife, arguing that "...But the daughter of Pharaoh led these other wives to change Solomon's heart to worship idols". ${ }^{29}$

What is also noteworthy about women as wives is the motherhood role which the women played in their families. In some cases, the latter role seems to be more pronounced compared to their roles as wives. The article on the "African wife of Joseph" 30 can serve as a case in point. Adamo's foregrounding of the house of Joseph is based on the two sons whom his African wife bore for him, namely, Manasseh and Ephraim - both were, in essence, Egyptian (African)

in the present case). Even Solomon's political life argues Adamo, was most probably advanced by the influence of his African/Egyptian wife with the marriage itself having been a political alliance.

27 See Anne Nasimiyu-Wasike, "Polygamy: A feminist critique," in The Will to Arise: Women, Tradition, and the Church in Africa (eds. Mercy Oduyoye and Musimbi R.A. Kanyoro, Maryknoll: Orbis, 1992), 108-118.

28 Adamo, "The African Wife of Solomon," 13.

29 Adamo, "The African Wife of Solomon," 14.

30 Adamo, "The African Wife of Joseph," 419 
citizens. He reasons: "One important fact is that Ephraim was an African born in Africa and is the descendant of Joseph and Asenath who were all truly Africans by birth and nationalization through elaborate rituals." 31 It appears Asenath's character is discussed more in relation to her father, the priest of Onan, than in relation to her husband. However, Asenath's contribution to Israel's tradition seems to be more in showing the African ancestry of Joseph's progeny and in essence, the ancestry of Israel, than her identity as a human being in her own right. Though at face value Asenath's contribution to Israel's tradition may give an impression of the affirmation of women, it conflates the critique with the elevation of the patriarchal status quo in which a woman is valued solely as a mother, especially a mother to (powerful) sons. What seems to happen in the narrative is that the initial attempt to foreground Asenath as an African wife of Joseph is overtaken by her role as a mother. However, the latter role gets superseded by Adamo's favourite theme on the presence of Africa and Africans in the HB.

Even in the case of the Hagar character, a very critical matriarch in the Islamic tradition, the African wife of Abraham seems to be celebrated more as a mother to Ishmael than as Abraham's wife. The article also reveals the relatively higher stature of Hagar in the Islamic tradition with her identity as a mother of Ishmael, one of pride not of shame. ${ }^{32}$ As could already be gleaned from the preceding discussion on the African biblical woman as wife (and mother), the women influenced the lives of their husbands, whether for good or for bad. As they were attached to men of stature, the women's influence on the men's lives would also filter through to the general public, reminiscent of the Woman of Worth in Proverbs 31:10-31. Although the Woman of Worth is the household manager par excellence, her influence, albeit indirect (filtered through her husband), could be felt at the city gates. In the following paragraphs, we take a look at Adamo's views on African biblical women's impacts on the communities as such, and thus their contribution in ancient Israelite history and in present day Bible readers' contexts.

\section{Woman as a Positive Agent for the Welfare of the Nation (Then and Today?)}

\section{3a African wife of Potiphar}

Adamo is persuaded that the African wife of Potiphar did what any other human being could do under the circumstances (of a sterile husband perhaps?). Through the wife of Potiphar's seduction followed by false accusations, Joseph ended up in jail. His gift of the interpretation of dreams was brought to Pharaoh's attention. His correct interpretation of dreams earns Joseph a high position; enables the country not only to be well prepared for the year of famine but also the survival

31 Adamo, "The African Wife of Joseph," 419.

32 Adamo and Eghwubare, "The African Wife of Abraham," 464. 
of the Hebrews in Egypt. Hence Adamo can reason: "The woman is pivotal to the survival of the Hebrews in Egypt. Her seduction initiated the event that brought the family of Jacob to Egypt, thus setting the stage for one of the major themes of the entire Bible, the Exodus or deliverance." ${ }^{33}$ One is not very certain how the preceding reading may be received by many a conservative African Bible reader on the continent in general and in the scholar's Nigerian context in particular.

\section{3b The African wife of Joseph (Asenath)}

As already noted in the section on the African Biblical woman, the African wife of Joseph is lauded more as a mother to sons. Even the sons' names are meant to celebrate the lives/experiences not of their bearer, but those of their father. Thus, the sons' names will suffice: Manasseh (meaning, God has made me forget all my trouble with the household of my father), and Ephraim (meaning, because God caused me to be fruitful in the land of my affliction) (cf. Gen. 41:50-52). Adamo then foregrounds the importance of the tribe of Ephraim (through whose name, the whole ten tribes came to be known). He also reveals Joshua's ancestry/lineage from the same tribe, thus showing Ephraim's importance to the life of ancient Israel. Besides the role that Ephraim and Manasseh and their descendants play in later Israelite history, Adamo foregrounds their African ancestry. What seems to be the pattern in the scholar's engagement with the women characters is that he hardly brings them to bear on the lived experiences of present-day African women. For example, in a Bible reading context in which the role of a woman as mother is no longer viewed as a given, but problematised, how may the role that Asenath played as a mother to powerful sons be viewed?

\section{3c The African wife of Abraham (Hagar)}

Out of the seven articles that engage African biblical women, the co-authored article on the African wife of Abraham is the one in which a deliberate effort is made to apply the narrative to the lives of present-day African women. The authors could thus contend: "It also attempts to relive one of the stories about African Biblical women, with the hope that contemporary African women will find in it a resource as they are confronted with a myriad of religious, social, and cultural problems in their faith journeys." ${ }^{34}$ The Hagar character is lauded as a paradigm for contemporary black women in terms of faith, courage, trust, perseverance and justice. Thus, Hagar played a significant role as an instrument of God in salvation history ${ }^{35}$. What is also different about this specific African woman is that the article foregrounds Hagar's relationship with the deity more than her relationship with a man as husband, a notable deviation from Adamo's other articles on women. In revealing the uniqueness of the Hagar texts from

33 Adamo, "The Nameless African Wife of Potiphar," 221.

34 Adamo and Eghwubare, "The African Wife of Abraham," 456.

35 Adamo and Eghwubare, "The African Wife of Abraham," 468. 
others in the HB, the authors argue as follows about the Hagar character: "The only non-Israelite non-male to receive a blessing as well as a visit from God. God's promises and compassion extend beyond the Israelites even as God's justice includes equality for women." 36

\section{3d The African wife of Jeroboam}

Another woman who could, according to Adamo, serve as a model for the lives of women, then and now, was the African wife of Jeroboam, a woman of courage and compassion. Unlike her husband Jeroboam, who was more concerned about the future of the throne than anything else, her courage was born out of compassion for her husband and the welfare/health of her son; thus bridging the gap between Jeroboam, their son, and Ahijah. Through her obedience, Jeroboam's African wife became the bearer of divine revelation, albeit for the nation's destruction. As a humble African woman who was obedient, she could obey the commands of her husband and the prophet through becoming an emissary between the two characters. Adamo also lauds Jeroboam's wife as an African woman of peace: "Sometimes, silence to a husband who is an abuser hurts the man more than arguments that may generate more beating" (2013:83). In the view of Adamo, silence is thus golden. ${ }^{37}$ Jeroboam's wife is depicted as one of dignity by the text.

\section{3e The African wife of Solomon}

As has already been noted earlier on, that the daughters are almost all Egyptian royals, Adamo notes some of the daughters' influence in the political, religious and economic lives of their husbands and of the nations (e.g., Jeroboam's wife and Solomon's wife). The women's Egyptian royal backgrounds as well as their husbands' connections with Egypt (either by sojourning and/or political ties) would have impacted on their forms of governance, the latter being a positive influence from Africa. Adamo could thus say concerning Solomon's African wife:

Pharaoh's daughter's influence was significant. Her economic, political and administrative contributions increased Israel's prosperity, and the political influence enabled Israel to have relative peace during Solomon's time. If all these contributions and influence are considered as an aspect of African contribution no one should

\footnotetext{
36 Adamo and Eghwubare, "The African Wife of Abraham," 463

37 In a context of gender-based violence that South Africa has become, the fact that silence should always be viewed as golden may not only be deemed problematic, it could actually be fatal. An unsettling study conducted by Isabel A. Phiri revealed that gender-based violence is also found in Christian households! See Isabel A. Phiri, "Domestic Violence in Christian Homes: A Durban Case Study," Journal of Constructive Theology 6/2 (2000): 85-110.
} 
deny the contribution of the daughter of Pharaoh who became Solomon's wife. ${ }^{38}$

\section{READING ADAMO'S WOMEN MATERIAL IN PRESENT-DAY SOUTH AFRICA}

In our attempt to bring Adamo's scholarship on women to bear on one of the present-day African contexts, the South African context will serve as a case in point. In the preceding context, where heterosexual marriage is still idolised ${ }^{39}$, despite the continued negative impact of the pandemic of HIV and AIDS and gender-based violence (even by clergy persons!), Adamo's foregrounding of the traditional role of woman as wife will be applauded, even by members of the younger generation. A recent case in point can be raised here, one that seems to have impressed even the local pastor. A young female was making a short presentation about the need for Christians to have faith in God. She then exhorted her peers who were aspiring for marriage to go to a specific jewellery shop (American Swiss) to fit a wedding ring in anticipation/preparation for what God was/is going to do in their lives.

On the other hand, though, the institution of marriage as it was traditionally understood (both in African cultures and the Christian tradition) is problematised by the following developments as examples. The rise of the Sugar Daddy and Sugar Mama phenomena, the rise of male blessers ${ }^{40}$ and female blessers ${ }^{41}$ including the high levels of divorce within black marriages not only problematise the traditional roles of husband and wife, they also destabilise many marriages in our contexts. Such developments thus tamper with the dignity traditionally accorded to a woman as wife and a man as husband. Problematic as the preceding developments, a bosadi approach would still persuade the readership to ask the following three crucial questions: (1) Does an African woman like many a female character engaged with by Adamo, need a man in a

38 David T. Adamo, "The African Wife of Solomon (I Kings 3:1;9:16; 7:8;11:1)," Journal for Semitics 23/1 (2014): 17.

39 See Marthe M. Kondemo and Madipoane Masenya (Ngwan'a Mphahlele), "What Now of the Problematic Norm: Rereading Heterosexual Marriage in the Book of Ruth within the Mongo Context of the DRC," in Navigating African Biblical Hermeneutics: Trends and Themes from our Pots and Calabashes (eds. Madipoane Masenya [Ngwan'a Mphahlele] and Kenneth Ngwa; New Castle Upon Tyne: Cambridge Scholars Publishing, 2018), 122-136.

40 Gerald O. West and Beverly G. Haddad, "Boaz as 'Sugar Daddy': Rereading Ruth in the Context of HIV in Southern Africa," in The Five Scrolls, Texts and Contexts (eds. Athalya Brenner-Idan, Gale Yee and Archie Lee; London: Bloomsbury T \& T Clark, 2018), 38-60.

41 Madipoane Masenya (Ngwan'a Mphahlele), "Reading Proverbs 7 in the Context of Female 'Blessers' and Sugar Mamas in South Africa," Scriptura 116/2(2017):120 132. 
heterosexual union to be affirmed as a full human being $?^{42}$ (2) In a povertyridden African context, a context which is plagued by the vast gap between the rich and the poor that South Africa is, how may texts about the African biblical women of class, women with socio-economic power be received? (3) Are poor women likely to easily embrace such biblical characters as models to be emulated? ${ }^{43}$

Apart from the contestations on the identity of Africans in our context, are the calls to the decolonisation of our Higher Education institutions' teaching and research. This is the same context in which the Christian Bible was used for better and for worse. It is a context riddled with contrasts as in the following example: a new development, especially among the African female youth of the "yellow bone" mentality can be contrasted with the calls and apparent yearnings to go back to "our roots" while the elevation of the calls to decoloniality can be contrasted with the elevation and celebration of the English language. In such a context, the celebration of the African presence in the Christian Bible, depending on one's religious orientation may be met with mixed feelings. The preceding observations notwithstanding, the contributions of Professor Adamo on African biblical women, especially given our predominantly androcentric biblical scholarship on the continent, should not only be welcomed. It should also be celebrated for bringing a refreshing twist to the broader discipline of African biblical hermeneutics.

\section{CONCLUSION}

This article sought to engage the following question: In Adamo's engagement with the issue of the African presence in the Hebrew Bible, does gender have a place, and if so, how? From the preceding discussion, gender as a concept does

42 Such a view will certainly not escape critique by African gender-identified women scholars. The following critique by Mercy A. Oduyoye on the androcentric language of selected African proverbs about the expectation that an African woman should necessarily be heterosexually married is worth noting: "The language of marriage proverbs indicates that a wife only reflects the stage of the marriage and a man's competence as a husband...Society demands that she stays married, because a woman has no dignity outside marriage." See Mercy A. Oduyoye, Daughters of Anowa: African Women and Patriarchy (Orbis: Maryknoll, 1995), 68 (italics-mine).

43 Marthe M. Kondemo would find biblical characters such as Queen Vashti, whose socio-economic class enabled her to say no to a problematic summon by a drunken husband, not a helpful model to poor African women within her Mongolese DR Congolese context (see, Kondemo, "In Search of Affirming Identities and Role Models," 122-136; See also Madipoane Masenya (ngwan'a Mphahlele), "Seeking Security Through Marriage: Ruth1:6-18 Placed Under an African Woman's HIV and AIDS Lens," Journal of Constructive Theology 13/2 (2007): 43-56). 
not have a place in Adamo's scholarship on women. Instead, in his commitment to argue about the presence of Africa and Africans in the Old Testament, Adamo has focussed on what he has called African biblical women. In the latter category, Adamo has focussed on the roles of the wives of men of class, especially those who have held the position of kingship (pharaohs). In foregrounding the role of biblical African women, Adamo has argued that the women have a place in God's divine scheme of things. In a nutshell, in our patriarchal African contexts, both on the continent and its Diasporas, an African male biblical scholar of Professor David Tuesday Adamo's generation, should be lauded for his deliberate efforts to retrieve the nameless female/women characters from the biblical text. He seems to be geared at rectifying the injustice of the namelessness and voice-less-ness accorded the characters by the predominantly male biblical narrators in his efforts to show that even African women played a role in the shaping of the story of Yahweh's dealings with God's people then, stories that may serve to encourage present-day women, especially Bible readers in Africa.

\section{F BIBLIOGRAPHY}

Adamo, David T. "The African Wife of Solomon (I Kings 3:1; 9:16; 7:8; 11:1)." Journal for Semitics 23/1 (2014): 1-20.

Adamo, David T. "The Nameless African Wife of Potiphar and her Contribution to Ancient Israel." OTE 26/2 (2013): 221-246.

Adamo, David T. "The African Wife of Joseph, Asenath (Gen. 41:45, 50; 46:20)." Journal for Semitics 22/2 (2013): 409-425.

Adamo, David T. "The African Wife of Jeroboam (Ano?): An African Reading of I Kings 14:1-18.” Theologia Viatorum 37/2 (2013): 71-89.

Adamo, David T. and Erivwierho F. Eghwubare. "The African Wife of Abraham." Old Testament Essays 18/3 (2005): 455-471.

Kondemo, Marthe M. "In Search of Affirming Identities and Role Models: A GenderSensitive Rereading of the Vashti and Esther Characters in the Book of Esther among the Mongo of the Democratic Republic of the Congo." Unpublished DTh thesis, University of South Africa, Pretoria, 2015.

Kondemo, Marthe M. and Masenya (Ngwan'a Mphahlele), Madipoane. "What now of the Problematic Norm: Rereading Heterosexual Marriage in the Book of Ruth within the Mongo Context of the DRC." Pages 122-136 in Navigating African Biblical Hermeneutics: Trends and Themes from our Pots and Calabashes. Edited by Madipoane Masenya (Ngwan'a Mphahlele) and Kenneth Ngwa. New Castle Upon Tyne: Cambridge Scholars' Publishing, 2018.

Maluleke, Tinyiko S. "African 'Ruths,' Ruthless Africans: Reflections of an African Mordecai." Pages 237-251 in Other Ways of Reading: African Women and the Bible. Edited by Musa W. Dube. Atlanta: SBL / Geneva: WCC Publications, 2001.

Masenya (Ngwan'a Mphahlele), Madipoane. "Reading Proverbs 7 in the Context of Female 'Blessers' and Sugar Mamas in South Africa." Scriptura 116/2(2017):120-132. https://doi.org/10.7833/116-2-1316. 
Masenya (Ngwan'a Mphahlele), Madipoane. "Seeking Security through Marriage: Ruth1:6-18 Placed under an African Woman's HIV and AIDS Lens." Journal of Constructive Theology 13/2 (2007): 43-56.

Masenya (Ngwana' Mphahlele), Madipoane. How Worthy is the Woman of Worth? Proverbs 31:10-13 in an African-South African Context. Peter Lang: New York, 2004.

Masenya (Ngwan'a Mphahlele) Madipoane and Ngwa Kenneth. Navigating African Biblical Hermeneutics: Trends and Themes from our Pots and Calabashes. Cambridge: Cambridge Scholars Publishing, 2018.

Mbuvi, Andrew. "African Biblical Studies: An Introduction to an Emerging Discipline," Currents in Biblical Research 15/2 (2017): 149-178. https://doi.org/ 10.1177/1476993x16648813.

Mudimeli, Lufhuluvi M. "The Impact of Religious and Cultural Discourses on the Leadership Development of Women in the Ministry: A Vhusadzi (Womanhood) Perspective." Unpublished DTh. thesis, University of South Africa, Pretoria, 2010.

Nadar, Sarojini. “A South African Womanist Reading of the book of Ruth.” Pages 159175 in Other Ways of Reading: African Women and the Bible. Edited by Musa W. Dube. Atlanta: SBL / Geneva: WCC Publications, 2001.

Nasimiyu-Wasike, Anne. "Polygamy: A Feminist Critique." Pages 108-118 in The Will to Arise: Women, Tradition, and the Church in Africa. Edited by Mercy Oduyoye and Musimbi R.A. Kanyoro. Maryknoll: Orbis, 1992.

Oduyoye, Mercy A. Daughters of Anowa: African Women and Patriarchy. Orbis: Maryknoll, 1995.

Oduyoye, Mercy A. and Kanyoro Musimbi A.R. The Will to Arise: African Women, Religion and Culture. Maryknoll: Orbis, 1989.

Phiri, Isabel A. "Domestic Violence in Christian Homes: A Durban Case Study." Journal of Constructive Theology 6/2 (2000): 85-110.

Ukpong, Justin S. "Developments in Biblical Interpretation in Africa: Historical and Hermeneutical Directions." Pages 11-28 in Bible in Africa, transactions, trajectories and trends. Edited by Gerald O. West and Musa W. Dube. Leiden: Brill, 2001.

West, Gerald O. and Haddad, Beverly G. "Boaz as 'Sugar Daddy': Rereading Ruth in the Context of HIV in Southern Africa." Pages 38-60 in The Five Scrolls, Texts and Contexts. Edited by Athalya Brenner-Idan, Gale Yee and Archie Lee. London: Bloomsbury T \& T Clark, 2018. https://doi.org/10.5040/97805 67678959.ch-004.

Madipoane Masenya (Ngwan'a Mphahlele), University of South Africa, Department of Biblical and Ancient Studies, and Acting Executive Director in the Principal and Vice Chancellor's Office, P O Box 392, 0003 Unisa, RSA. masenmj@unisa.ac.za. ORCID: https://orcid.org/0000-0001-7373-2454. 